\section{Trusler og Tyvekoster -}

\section{Tale ved udstillingsåbningen 11. maj 2006}

af seniorforsker, dr.phil. Karen SkovgaardPetersen

I 1728 brændte Københavns Universitetsbibliotek og hele dets bestand af bøger. Historikeren og bogsamleren Arne Magnussøn skrev kort efter i et brev: I Biblioteket oven på Trinitatis Kirke vare mange Ting, som Verden nu ikke mere eier; hvilken Skade kan ikke afhielpes.

Med denne nøgterne konstatering af det uigenkaldelige tab branden afstedkom, gav Arne Magnussøn udtryk for samme tankegang som den der mange år senere, i 1992, lå bag UNESCOs lancering af det store Memory of the World -program. Programmet tager udgangspunkt i den erkendelse at der hver dag rundt om i verden går uerstatteligt materiale tabt i form af bøger og arkivalier, materiale der, som det hedder, afspejler verdens kulturelle mangfoldighed. Med programmet vil UNESCO bidrage til at beskytte den skrevne kulturarv - en lidt højtidelig men praktisk betegnelse - mod alle de forskellige natur- og menneskeskabte farer der truer den.

Blandt de trusler som Memory of the World-programmet skal medvirke til at afværge, er naturligvis også tyveri. Det er baggrunden for at vi har slået de to oprindeligt separat planlagte udstillinger sammen - den ene skulle vise de værker der fra dansk side er nomineret til UNESCOs Memory of the World-liste, den anden skulle handle om det store bogtyveri som ramte
Det Kongelige Bibliotek i 1970erne og som fornylig er blevet opklaret.

I stedet for kun at behandle bogtyveriet har vi udvidet perspektivet og ladet første del af udstillingen handle mere generelt om trusler mod bibliotekers og arkivers samlinger. Det er en global problemstilling, men den lader sig udmærket belyse i Det Kongelige Biblioteks samlinger. De trusler vi berører, er hærværk, krig/krigsbytte, brand og ligegyldighed - og så naturligvis tyveri. For 'det store bogtyveri' spiller stadig en hovedrolle.

At bøger og arkivalier lever et udsat liv skulle gerne fremgå tydeligt - og det bliver yderligere demonstreret i den næste sektion, hvor vi ser nærmere på bøgerne selv, på hvad der sker med dem når de udsættes for brand, vand og diverse skadedyr (hvortil regnes mennesket). Denne del af udstillingen står konservatorerne Magdalena

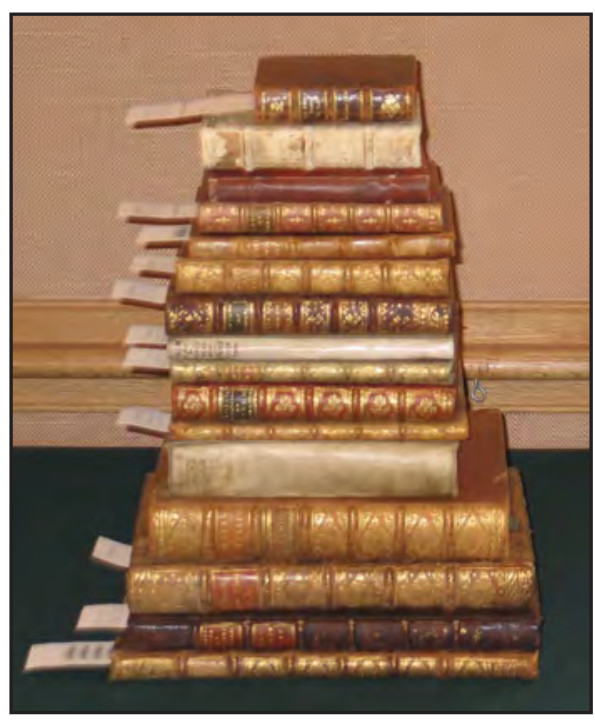

De boger der blev indleveret af tyvens familie til auktionshuset Christie's i London. Fotograferet af chefsikkerhedsrådgiver ved Det Kongelige Bibliotek Jesper Düring Jørgensen hos Christie's. 
Midtgård og Sidse Stammerjohan og deres team for. Med pædagogisk sans for stærke effekter viser de skrækeksempler på bøger, eller rettere rester af bøger, der er blevet fortæret af biller, svamp, fugt og flammer. Heldigvis făr vi også mere opmuntrende indsigt $\mathrm{i}$ hvordan konservatorens indsats kan redde en truet bog fra at gå til.

Til sidst i udstillingen vil den besøgende så nå frem til at se på Memory of the World-værkerne - altså de værker og samlinger som Danmark har nomineret til optagelse på listen inden for de sidste 10 år. Det er værker som har undgået de mange trusler, eller i hvert fald undgået at bukke under for dem - og som vi skal blive ved med at passe godt på.

\section{Det store Bogtyveri}

I det følgende vi jeg gå lidt nærmere ind på den første del, om truslerne. 'Det store bogtyveri' er som sagt hovedsagen i denne del af udstillingen. Hensigten har været at rette opmærksomheden på bøgerne selv. Vi viser alle de stjålne bøger der blev fundet hos tyven og hans familie. Det gør vi ikke bare fordi alle disse gamle bøger er et imponerende syn - men også fordi vi gerne vil give et indtryk af hvad det er for nogle bøger. Tyven har tydeligvis gået efter hvad

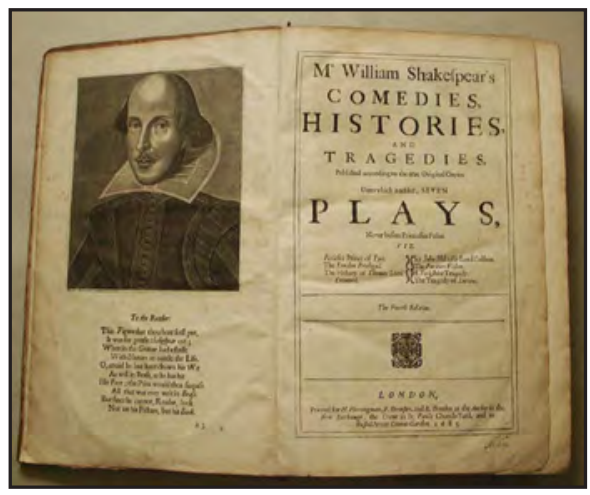

der var penge $i$, nemlig bøger fra 15-16- og 1700-tallet, såvidt muligt illustrerede. Også indholdsmæssigt falder bøgerne inden for nogle kategorier som er populære på det internationale samlermarked. Store navne i verdenslitteraturen er stærkt repræsenteret, såsom Thomas More, Erasmus af Rotterdam, Goethe. Tilsvarende finder man mange klassikere inden for videnskabs- og filosofihistorien, bl.a. Giordano Bruno, René Descartes og Immanuel Kant. Et andet tyngdepunkt er teologi, især reformationstidens litteratur. Faktisk er Luther den forfatter der er hyppigst repræsenteret blandt de genfundne bøger - hvad der nu nok også hænger sammen med at Luther-trykkene er små og tynde og lette at luske ned i en taske. Og endelig har bogtyven været klar over at bøger fra 15-1600-tallet der handler om Amerikas opdagelse og kolonisering, går til skyhøje priser blandt amerikanske samlere. Dem er der en del af blandt hans rov.

\section{Andre bogtyve}

$\mathrm{Nu}$ var vores grådige bogtyv fra 1970erne ikke den første bogtyv i historien. Vi har forsøgt, antydningsvis, at give et lidt bredere billede af fænomenet bogtyveri. I Det Kongelige Bibliotek findes flere fine middelalderhåndskrifter som - muligvis engang har skiftet ejer ad uærlig vej. Den lærde tysker Friedrich Lindenbrog blev i sin samtid, i begyndelsen af 1600-tallet, beskyldt for at have hugget en del middelalderlige håndskrifter fra parisiske biblioteker. Hvordan han nu end fik fat i dem, så afhændede han dem siden til hertugbiblioteket på Gottorp Slot i Slesvig. Herfra kom de så 100 år senere som krigsbytte til Det Kongelige Bibliotek - og i dag er de blandt de absolutte klenodier i samlingerne. Det drejer sig bl.a. om et håndskrift (GKS 20) hvori Friedrich Lindenbrog ikke bare 


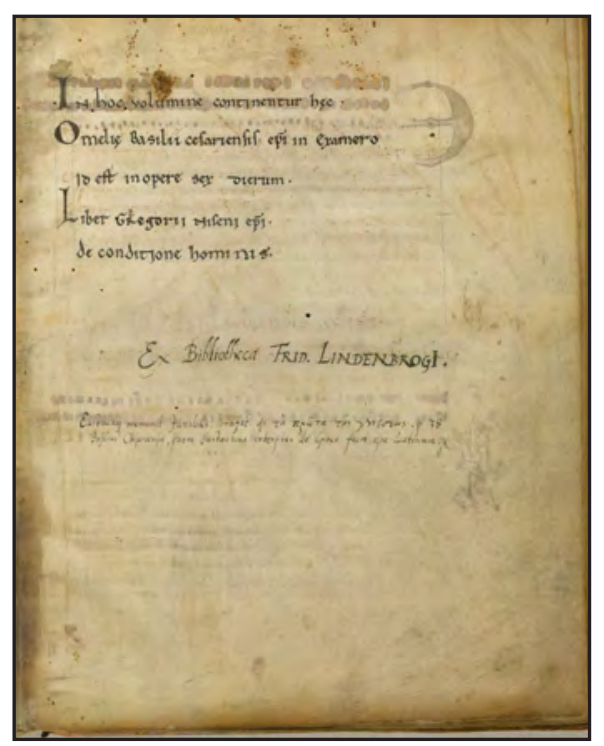

har skrevet sit navn tydeligt, men også formentlig - gjort sig ihærdige anstrengelser for at slette et tidligere navn. Netop denne

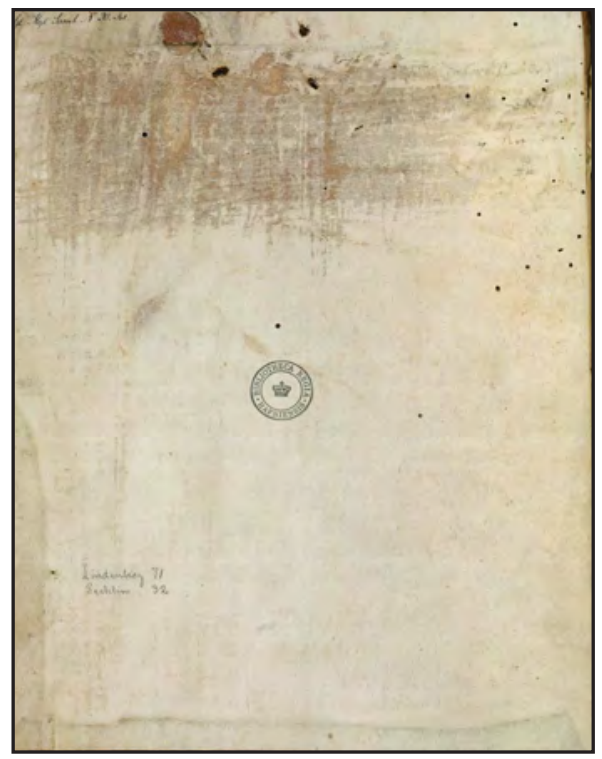

heftige udradering er blevet taget som et indicium på at han ikke havde rent mel i posen. Men faktisk er det helt almindeligt i ældre bøger at se at senere ejere sletter tidligere ejernavne, omend det her nu er usædvanligt hidsigt. Mistanken til Lindenbrog er kun en mistanke. Det kan være vanskelig på flere hundrede års afstand at vurdere hvor berettigede tyveri-anklagerne er - og et lille spørgsmålstegn ved Lindenbrogs tyvagtige virksomhed tillader vi os at stille i udstillingen.

Bøger kan også blive udsat for hærværk og få fjernet enkelte sider eller dele af sider. Typisk drejer det sig om særlig smukke eller værdifulde dele af bøgerne, fx i et fint pergamenttryk fra 1485, Breviarium ... Augustanum (inc. haun. 890), der har været udsat for, som det hedder i Chr. Molbechs katalog over bibliotekets pergamenttryk (1830), en 'Niddings tyvehånd'. Denne nidding har fjernet hvad der formodentlig var bogens fineste pryd, måske et håndkoloreret våbenskjold.

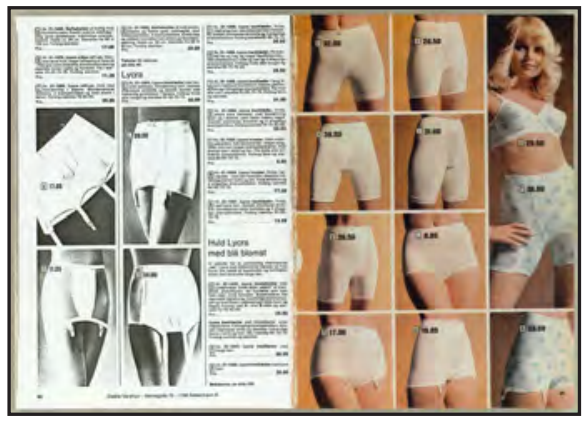

Det er ikke kun ældre værker der er udsatte for den slags mishandling. Efterår-vinterkataloget 1971 fra Daells Varehus har også været genstand for en langfingret læsers interesse. Der mangler nu nogle sider med dameundertøj, skåret ud på læsesalen. Men biblioteket har, som man kan se, samvittighedsfuldt repareret på skaden ved at fremskaffe fotokopier af de stjålne sider. 


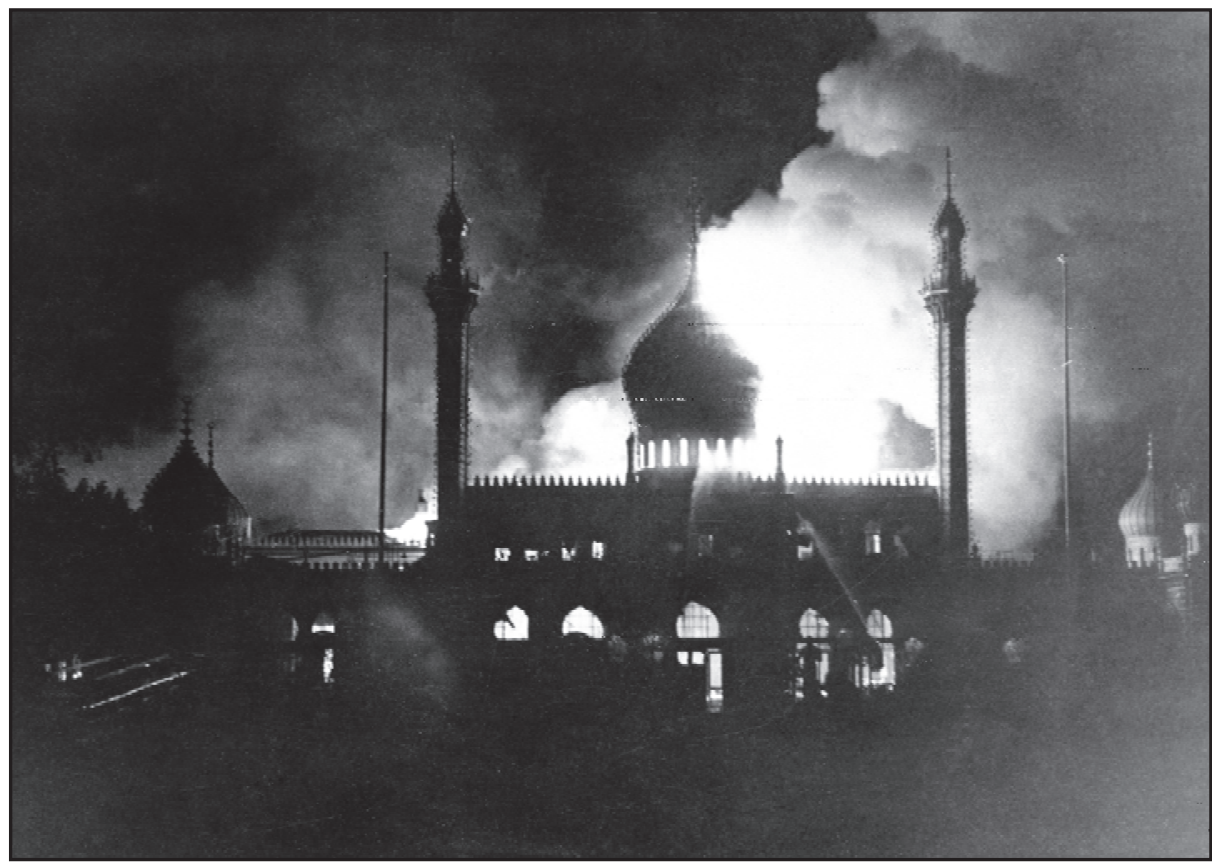

Tivolis brand august 1944. Koncertsalens musikarkiv gik tabt ved denne lejlighed, men nogle af noderne er blevet reddet (Det Kongelige Bibliotek).

\section{Brand}

T angt den største trussel mod bøger og arkivalier er imidlertid ild. Selv den mest ihærdige bogtyvs mangeårige indsats blegner mod hvad en brand kan anrette af skader på nogle timer. I dansk sammenhæng er den største katastrofe Universitetsbibliotekets brand i 1728. Hele biblioteket brændte, og dermed gik omkring 35.000 bøger og håndskrifter tabt. Det har derfor været naturligt i udstillingen, som illustration af truslen 'brand', at forsøge at give et indtryk af hvad det var for et bibliotek der blev flammernes bytte, hvori det kulturhistoriske tab bestod.

Man plejer gerne, og med rette, at beklage alle de middelalderlige håndskrifter der gik op i luer i 1728 . Hvis de havde overlevet, ville vi vide meget mere om Danmarks historie i middelalderen. Men biblioteket var også rigt på trykte værker inden for mange fag. Det blev i løbet af 1500-tallet og især i 1600-tallet et alsidigt forskningsbibliotek, der klart overgik kongens bibliotek, Det Kongelige Bibliotek. Bl.a. kunne man her finde de nyeste naturvidenskabelige landvindinger i 1500 tallet, som hurtigt blev anskaffet til universitetsbiblioteket - man har tydeligvis fulgt godt med på det europæiske bogmarked. Dem kan vi vise i udstillingen fordi Universitetsbiblioteket og Det Kongelige Bibliotek siden har anskaffet andre eksemplarer af disse værker. Her ses, fra Vesalius' banebrydende anatomiske værk De humani corporis fabrica libri septem fra 1543 , et billede af et skelet, der ser ud til at grunde over altings forgængelighed.

Hvad vi derimod ikke kan vise, er de ikke helt få trykte, danske bøger 


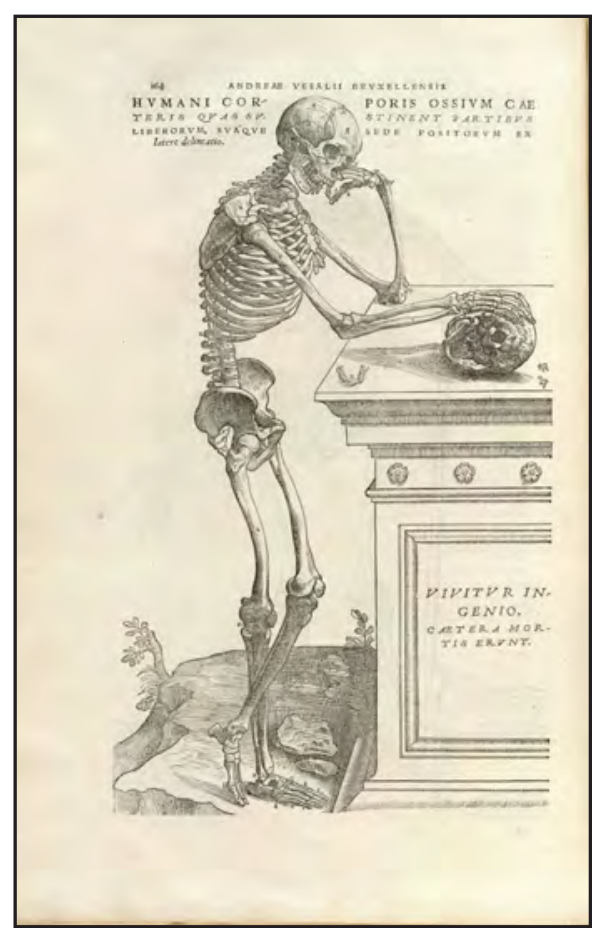

De humani corporis fabrica libri septem, 1543 (Det Kongelige Bibliotek).

der brændte med Universitetsbiblioteket og som ikke er bevaret $\mathrm{i}$ andre eksemplarer. Der er ikke tvivl om at vi ville have et bedre kendskab til 1500-tallets danske litteratur hvis ikke Universitetsbiblioteket var brændt.

\section{Ligegyldighed}

$\mathrm{D}$ et er jo i selv tankevækkende at alle andre eksemplarer af disse danske bøger - det drejer sig fx om en 'håndbog om brudevielse og døbelse' fra 1531-er gået tabt. Ingen har åbenbart gidet tage vare på dem. Hermed er vi ovre i en helt anden slags trussel mod den skrevne kulturarv, som vi også beskæftiger os med i udstillingen, nemlig ligegyldighed. I modsætning til de fleste andre trusler, såsom brand og krig og vandskader, er ligegyldighed en snigende fare, ikke spor iøjnefaldende. Og blandt dens ofre er altså mange danske bøger fra 1500-tallet.

Men endnu ældre tekster, fra antikken og middelalderen, har hængt i en særlig tynd tråd, fordi deres overlevelse dengang, før trykkekunstens opfindelse midt i 1400-tallet, var afhængig af at de blev bevaret i håndskrifter. Meget er gået tabt og meget har overlevet med nød og næppe. En af de antikke digtere vi i dag sætter højt - og det gælder også uden for fagspecialisternes kreds - er Catul. Men i middelalderen var hans digte stort set ikke læst. Engang i 1300-tallet blev man imidlertid, i lærde kredse i Italien, opmærksom på et enkelt håndskrift med disse ellers ukendte tekster, man begyndte at læse dem, fik taget afskrifter af dem, lod sig inspirere af dem - og da det så, ikke længe efter, blev muligt for alvor at mangfoldiggøre tekster gennem bogtrykket, var Catuls digte sikret

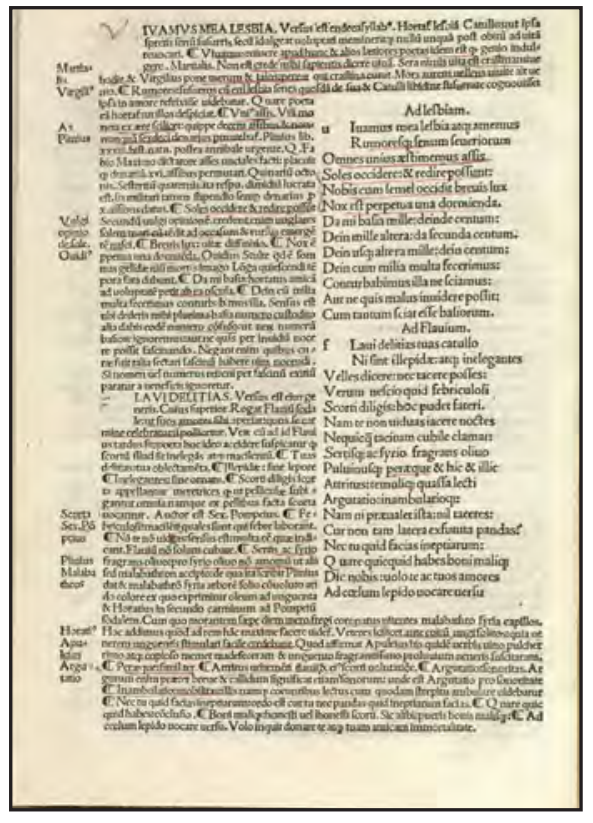


en stor og interesseret læserskare, og det har de haft siden. Men det er altså faktisk lidt af et held at vi overhovedet kender dem i dag. Pointen er at der skal læsere til, der skal være nogle der interesserer sig for teksterne, for at læse dem og diskutere dem. Vi skal passe godt på de gamle bøger, det siger sig selv - gøre hvad vi kan for at beskytte dem mod brand og vand og tyveri og hærværk og krig og skadedyr og såmænd også almindelig slid - men til ansvarlig bevaring hører det også at sørge for at bøgerne kan blive læst og studeret. Ellers sygner de hen og dør af ligegyldighed.

Og hermed er vi tilbage ved UNESCO. Det er nemlig et hovedpunkt i Memory of the World-programmet at så mange mennesker som muligt verden over skal have adgang til den skrevne kulturarv, skal lære nogle af de værker at kende som den består af, og blive bevidste om at de udgør en del af vores kollektive hukommelse, forstå at de er værd at bevare. Derfor er digitalisering og internetpublicering et centralt element i Memory of the Worldprogrammet, for herved kombineres langt hen ad vejen universel tilgængelighed med ansvarlig bevaring.

Flere af værkerne som er nomineret til Memory of the World-listen fra dansk side, er netop også blevet gjort tilgængelige digitalt. Det gælder de vestindiske lokalarkiver, hvor Rigsarkivet har lagt en detaljeret arkivregistratur på deres hjemmeside om Dansk Vestindiens historie (www.virgin-islands-history.dk), og det gælder Det Kongelige Biblioteks portal om Guaman Pomas Inka-krønike.

At slå to udstillinger sammen til én kan lyde som en arbejdsbesparende foranstaltning. Det kan jeg roligt sige at der ikke været tale om. Mange mennesker har knoklet i uger og måneder, så mange at jeg ikke vil nævne navne, men blot sige at det er en stor oplevelse at deltage i det teamwork det er at stable en udstilling på benene.

En helt særlig udfordring har sammentænkningen af de to udstillinger været for den der skulle udtænke de fysiske rammer. Jeg har været utrolig glad for at Henriette Willerup påtog sig opgaven som udstillingsarkitekt. Med stor iderigdom og lydhørhed over for udstillingens indhold har hun forbundet de forskellige dele af udstillingen i en smuk og virkningsfuld helhed - og det synes jeg I om lidt skal gå ned og konstatere ved selvsyn.

Udstillingen Trusler og tyvekoster. UNESCOs Memory of the World-program og de mange farer de truer den skriftlige kulturarv vises indtil 12. august 2006. 